\title{
EFFECTS OF N ITROGENADDITIONON THE CHARACTERISTICS OF FOLIAR AND SOIL ECOLOGICAL STOICHIOMETRY IN XISHUANGBANNA TROPICAL RAINFOREST, SOUTHWEST CHINA
}

\author{
Niu J, Lu TP, Lin YJ \& Zhang WX* \\ Yunnan Key Laboratory of Plateau Geographical Process and Environmental Change, Yunnan Normal University, Kunming \\ 650500, China \\ *wenxiangzhang@ynnu.edu.cn
}

Submitted October 2018; accepted July 2019

\begin{abstract}
Xishaungbanna tropical rainforest (XTR) is the most intact tropical rainforest in China, and is the only oasis at around 21 degrees north latitude. The purpose of this study was to explore the effects of nitrogen $(\mathrm{N})$ exogenous input on ecological stoichiometry of soil and foliar, and to assess the impact on the ecosystem of XTR. The results showed that the N content and nitrogen:phosphorus (N:P) in soil of XTR were increased significantly in different levels of $\mathrm{N}$ addition, especially in the low $\mathrm{N}$ addition. The $\mathrm{P}$ content in soil and leaves was generally reduced or flat compared with those before $\mathrm{N}$ addition. Meanwhile, $\mathrm{N}: \mathrm{P}$ of soil had a significant relationship with the $\mathrm{N}$ and $\mathrm{P}$ content after $\mathrm{N}$ addition. However, the correlated coefficient between $\mathrm{N}: \mathrm{P}$ and $\mathrm{N}, \mathrm{P}$ content of plant leaves was significantly reduced by the $\mathrm{N}$ addition, respectively. This indicated that the impact of $\mathrm{N}$ deposition on the XTR ecosystem is very significant. Therefore, increase of $\mathrm{N}$ deposition may intensify the limiting effect of $\mathrm{P}$ in ecosystems, and aggravate the patchiness and degradation of XTR ecosystem due to global warming.
\end{abstract}

Keywords: Nutrient addition, nitrogen and phosphorus stoichiometry, limiting element, tropical rainforests ecosystem, tropical northern rim

\section{INTRODUCTION}

Nitrogen $(\mathrm{N})$ is a key nutrient element that affects species composition, diversity and dynamic function of ecosystems. Many plants are adapted to coexist under low $\mathrm{N}$ environment (Sala and Wall 2000). Therefore, the increase of $\mathrm{N}$ input is considered to be one of the greatest threats to the biodiversity of terrestrial ecosystems (De Schrijver et al. 2011, Mori et al. 2017). Frequent human activities have promoted nutrients into the ecosystem and aggravated eutrophication. All of this profoundly affect terrestrial ecosystems and their nutrient cycling (Galloway and Sutton 2008). The global atmospheric $\mathrm{N}$ deposition increased from 15 to $187 \mathrm{Tg} \cdot \mathrm{a}^{-1}$ in the past 150 years (Sutton and Bleeker, 2013). As one of the three largest acidic deposition areas in the world, the annual deposition atmospheric $\mathrm{N}$ flux amounted to $12.9-21.1 \mathrm{~kg} \cdot \mathrm{ha}^{-1} \cdot \mathrm{a}^{-1}$ in China, and $\mathrm{N}$ deposition reached up to $99-117 \mathrm{~kg} \cdot \mathrm{ha}^{-1} \cdot \mathrm{a}^{-1}$ in certain areas, e.g. agricultural area in north China plain (Liu et al. 2013). Artificial $\mathrm{N}$ addition experiment in the field, which is an important method of simulating the effect of natural $\mathrm{N}$ deposition on ecosystem, has been widely used to study the ecosystem of temperate forest, grassland and subtropical evergreen broadleaved forest (Storkey et al. 2015). However, in tropical rainforest this research is widely lacking. Ecological stoichiometry can be used to reveal the nutrient distribution, limiting factors of plant growth and the relationship between plants and soil (Giardina \& Ryan 2002). Previous research has shown that the content of $\mathrm{N}$, phosphorus $(\mathrm{P})$ and N:P in plants can reflect the dynamic balance between soil nutrient supply and plant nutrient requirement (Tessier \& Raynal 2003). Moreover, N:P has also been used to diagnose plant communities and ecosystems, and to analyse nutrient limitation patterns of $\mathrm{N}$ and $\mathrm{P}$ on the global scale (Han et al. 2005, Guo et al. 2014). These studies in China were mainly concerned with grassland ecosystems, wetland ecosystem, 
subtropical forest ecosystem and plantation in Northern China (Lü et al. 2013, Zhao et al. 2014, Li et al. 2016, Xu et al. 2017). However, the research of ecological stoichiometry in Chinese tropical areas is less, especially in the tropical rainforest ecosystem, and needs to be further strengthened.

Xishuangbanna is in Yunnan Province, southwest of China, and located in the tropical northern rim. It is controlled by the Asian southwest monsoon, and is the only distribution area of tropical rainforest in the Tropic of Cancer (Myers et al. 2000, Zhang et al. 2018). It becomes one of the intense scientific interest area of Indo-Burma and global bio-diversity conservation reserves because of the abundant biological resources (Lu et al. 2017). However, a large amount of $\mathrm{N}$ emissions (e.g. $\mathrm{N}$ fertilisation, fuel consumption and biomass burning) cause an increase of active nitrogen in Xishaungbanna tropical rainforest (XTR) ecosystem through atmospheric dry and wet deposition (Liu et al. 2013). This has seriously affected the biodiversity resources of XTR, and led to serious degeneration of eco-environment degradation.

To examine the responses of foliar and soil ecological stoichiometry to increasing $\mathrm{N}$ deposition, an experiment of $\mathrm{N}$ addition was conducted in XTR, southwest China. The N, $\mathrm{P}$ content and N:P of leaves and soil of the dominant species were investigated in XTR, as well as the relative restrictive effects of $\mathrm{N}$ and $\mathrm{P}$ nutrient patterns on biomass. This study can provide vital reference for succession trend of phytobiocoenose in tropical rainforest under increasing atmospheric nitrogen deposition.

\section{MATERIALS AND METHODS}

\section{Study area}

Xishuangbanna is in the down-stream area of Lancang-Mekong River in Yunnan province, bordering Laos and Burma, located in southwestern China (Figure 1). It belongs to the tropical monsoon climate in the north edge of the tropics. The mean annual temperature is $21.5^{\circ} \mathrm{C}$, and the mean annual precipitation is approximately $1550 \mathrm{~mm}$, with more than $80 \%$ falling between May and October. The Annual sunshine hours of Xishaungbanna exceed 1800 hours. Approximately 170 days throughout the year are foggy days, and the area is frost-free all year round (Lu et al. 2017). The undulating terrain and hilly areas are the most widely distributed in Xishaungbanna, accompanied by an intermontane basin and river terraces. The XTR is the highest latitude area in the world, and its ecosystem is mainly composed of tropical seasonal rainforest and tropical mountain rainforest; soil of distribution is mainly lateritic red soil (Fang \& Sha 2006). The soil N and $\mathrm{P}$ content are 1.87 and $0.56 \mathrm{mg} \cdot \mathrm{g}^{-1}$ ( $\mathrm{Lu}$ et al. 2018). The dominant plant species of the tropical seasonal rainforest are Pometia pinnata, Terminalia myriocarpa and Parashorea chinensis, and

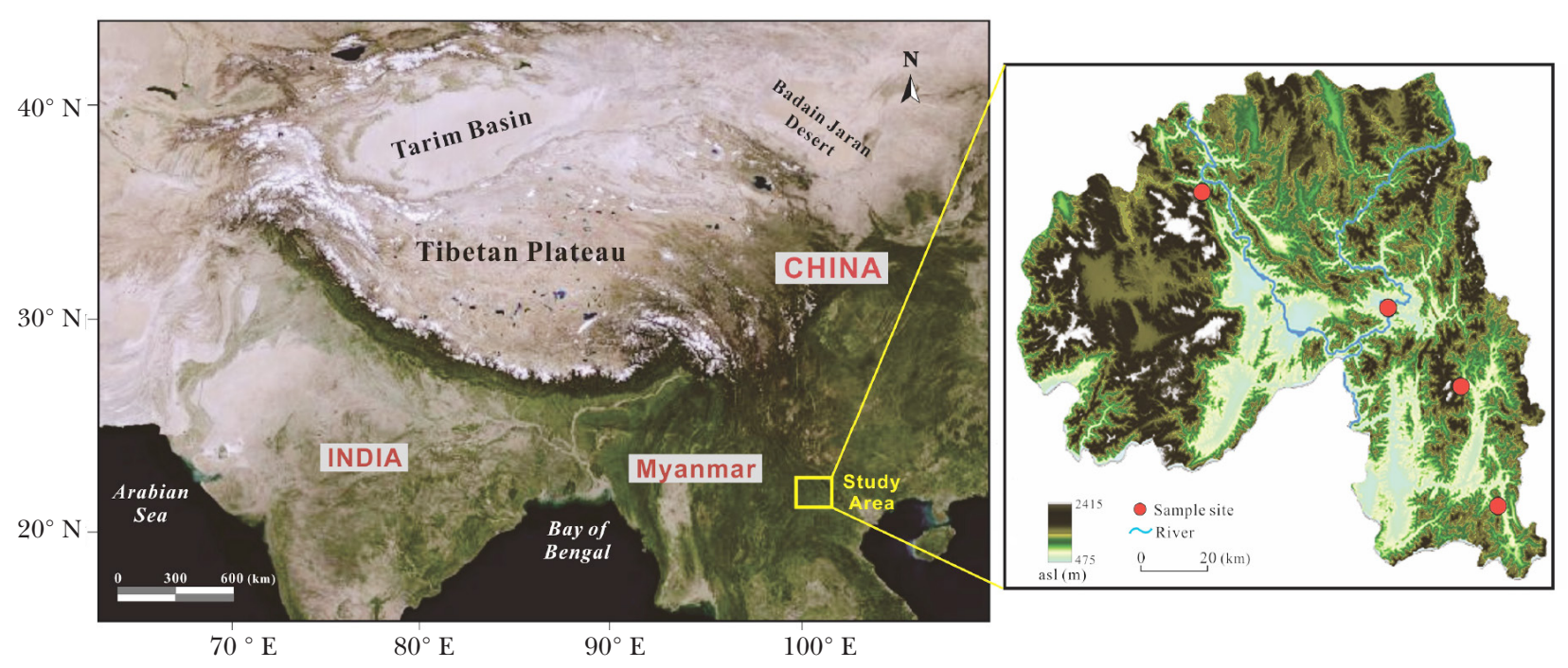

Figure 1 The location of sample sites in Xishaungbanna tropical rainforest (XTR) 
that of tropical mountain rainforest are Mastixia euonymoides and Calophyllum polyanthum (Zhu et al. 2012).

\section{Plot layout and sampling}

The objective of the study is to simulate the effect of atmospheric $\mathrm{N}$ deposition on tropical rainforest ecosystem, with reference to the real atmospheric $\mathrm{N}$ deposition of $9.8 \mathrm{~kg} \mathrm{~N} \mathrm{ha}^{-1}$ in the area (Lu et al. 2018). Therefore, four levels of $\mathrm{N}$ addition were applied in the four blocks of XTR during the plant growing season in July 2016 and 2017: $0 \mathrm{~kg} \cdot \mathrm{N} \cdot \mathrm{ha}^{-1}(\mathrm{CK}), 20 \mathrm{~kg} \cdot \mathrm{N} \cdot \mathrm{ha}^{-1}$ $(\mathrm{LN}), 40 \mathrm{~kg} \cdot \mathrm{N} \cdot \mathrm{ha}^{-1}(\mathrm{MN})$ and $60 \mathrm{~kg} \cdot \mathrm{N} \cdot \mathrm{ha}^{-1}(\mathrm{HN})$. The $\mathrm{N}$ addition was treated in the available fertiliser $\left(\mathrm{NH}_{4} \mathrm{NO}_{3}\right)$, and the experiment used a completely randomised block design. There were four blocks and each block had four plots. Each typical plot was $10 \times 10 \mathrm{~m}$, with $10 \mathrm{~m}$ wide buffer zone between adjacent plots. Thirty-two soil cores $(10 \mathrm{~cm}$ in diameter, $10 \mathrm{~cm}$ in depth) were used to collect the soil samples in XTR. Meanwhile, 15-20 leaves of the dominant species, exposed to sun and one third of the canopy, were collected by using high branch scissors in each typical plot. All samples were collected twice a year in 2016 and 2017, once in July before the planned addition of nitrogen, and another in September of plant harvest. The samples were sealed in plastic bags and transported to the laboratory for analysis of $\mathrm{N}$ and $\mathrm{P}$.

\section{Experiment and analysis}

The samples were sifted to remove stones, plant roots and petiole using a 2 -mm sieve. The preparation involved complete airdrying of the samples, grinding and sieving at $75 \mu \mathrm{m}$ to remove plant residues. The $\mathrm{N}$ and $\mathrm{P}$ content of the soil and leaves were determined with elemental analyser and molybdenum colorimetric blue method respectively (Murphy $\&$ Riley 1962). The relative standard deviation (RSD) of parallel analyses of individual samples was $<3 \%$. The analysis data of this study were the mean values of $\mathrm{N}$ and $\mathrm{P}$ in September 2016 and 2017, and 32 data (soils and leaves) were obtained. Statistical analysis was performed using $\mathrm{R}$ software. The one-way ANOVA was performed to analyse the impacts of $\mathrm{N}$ addition, and Pearson correlation was used to test the significance of correlations.

\section{RESULTS}

\section{Response of $\mathbf{N}$ and $\mathbf{P}$ content in soil and leaves to $\mathrm{N}$ addition}

Analysis of N content in the soil of XTR showed that the $\mathrm{N}$ content in soil increased from $1.72 \mathrm{mg} \cdot \mathrm{g}^{-1}\left(1.22-2.69 \mathrm{mg} \cdot \mathrm{g}^{-1}\right)$ before $\mathrm{N}$ addition, to $2.26 \mathrm{mg} \cdot \mathrm{g}^{-1}\left(0.84-4.45 \mathrm{mg} \cdot \mathrm{g}^{-1}\right)$. The regularity of the $\mathrm{N}$ content in the soil of XTR is as follows: $\mathrm{LN}>\mathrm{MN}>\mathrm{HN}$ (Figure 2A). The LN addition had the most significant impact on $\mathrm{N}$ content in soil, ranging from 1.50 to $2.66 \mathrm{mg} \cdot \mathrm{g}^{-1}$. The increasing extent of $\mathrm{N}$ content in soil displayed the following order of abundance: $\mathrm{LN}(77.52 \%)>\mathrm{CK}(16.12 \%)$ $>\mathrm{MN}(15.39 \%)>\mathrm{HN}(8.58 \%)$. Meanwhile, the standard error (SE) of $\mathrm{N}$ content in soil increased significantly after the addition of $\mathrm{N}$. But the $\mathrm{P}$ content in soil showed a decreasing trend after $\mathrm{N}$ addition (Figure 2B). The $\mathrm{SE}$ change of $\mathrm{P}$ content in soil was similar to that of $\mathrm{N}$ content, showing a significant increase after $\mathrm{N}$ addition.

The $\mathrm{N}$ content in dominant species leaves of XTR decreased firstly, and then increased from $\mathrm{LN}$ to HN (Figure 2C). Under the condition of $\mathrm{LN}$ addition, The $\mathrm{N}$ content in dominant species leaves reduced significantly. On the contrary, the $\mathrm{N}$ content increased slightly by $\mathrm{MN}$ and $\mathrm{HN}$ addition. The $\mathrm{P}$ content in the dominant species leaves decreased in treatments of $\mathrm{CK}, \mathrm{LN}$ and $\mathrm{HN}$, and remained stable or increased slightly in the MN addition experiment (Figure 2D). This indicated that the SE of $\mathrm{N}$ and $\mathrm{P}$ content in dominant species leaves was approximately flat or decreasing after $\mathrm{N}$ addition.

\section{Response of $N: P$ in soil and leaves to $N$ addition}

The $\mathrm{N}$ content of soil in XTR increased significantly after $\mathrm{N}$ addition, while $\mathrm{P}$ content showed a decreasing trend. Therefore, all N:P ratio in the soil was increased after $\mathrm{N}$ addition, especially after the addition of LN (Figure $3 \mathrm{~A})$. However, $\mathrm{N}: \mathrm{P}$ in dominant species leaves generally showed a decreasing trend after $\mathrm{N}$ addition, except for $\mathrm{HN}$, which increased slightly (Figure 3B).

\section{The relationship between $\mathrm{N}, \mathrm{P}$ and $\mathrm{N}: \mathrm{P}$}

Based on the study of the correlation between $\mathrm{N}, \mathrm{P}$ content and $\mathrm{N}: \mathrm{P}$ ratio, it is shown that there is no obvious correlation in the soil 

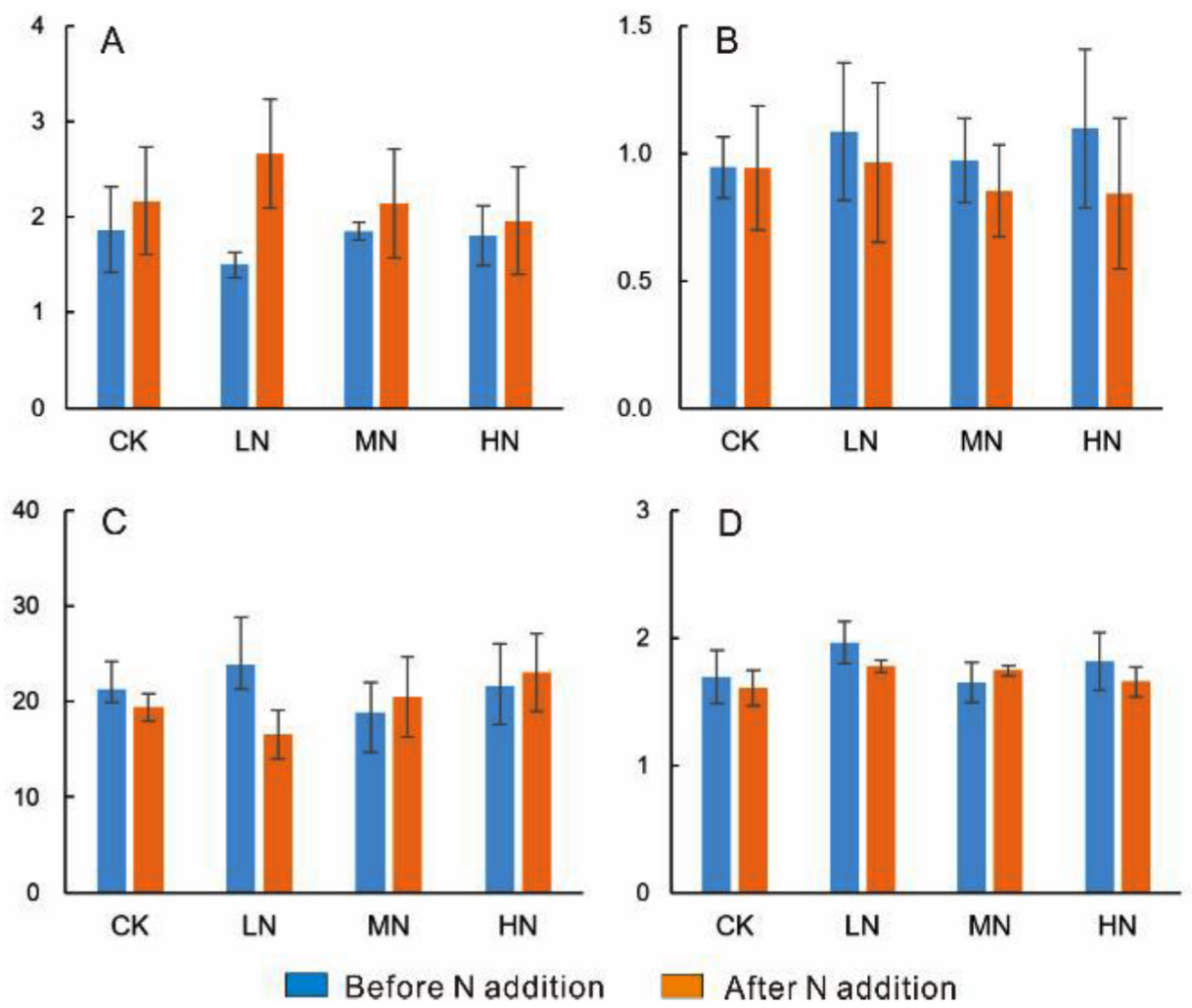

Figure 2 The effects of $\mathrm{N}$ addition on $\mathrm{N}$ and $\mathrm{P}$ content of soil and leaves (mean \pm S.E.); (A) $\mathrm{N}$ content in soil $\left(\mathrm{mg} \cdot \mathrm{g}^{-1}\right),(\mathrm{B}) \mathrm{P}$ content in soil $\left(\mathrm{mg} \cdot \mathrm{g}^{-1}\right),(\mathrm{C}) \mathrm{N}$ content in the dominant species leaves $\left(\mathrm{mg} \cdot \mathrm{g}^{-1}\right)$, (D) $\mathrm{P}$ content in the dominant species leaves $\left(\mathrm{mg}^{\circ} \mathrm{g}^{-1}\right)$; significant at $\mathrm{p}<0.05$
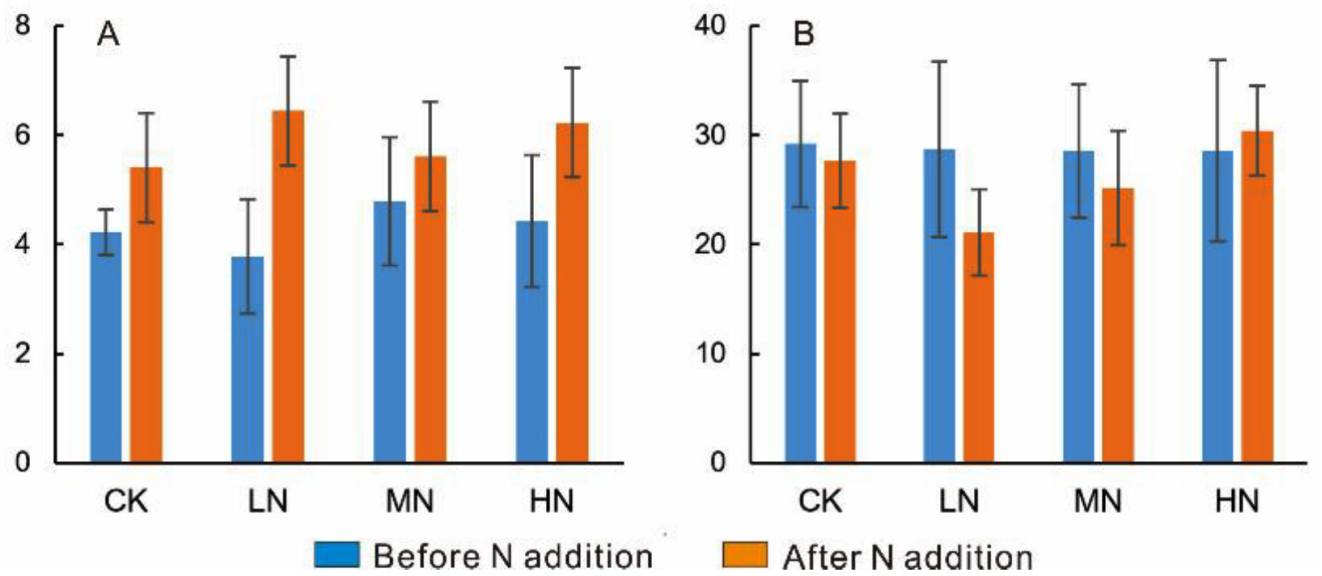

Figure 3 The effects of $\mathrm{N}$ addition on N:P of soil and leaves (mean \pm S.E.); (A) N:P in soil, (B) N:P in the dominant species leaves; significant at $\mathrm{p}<0.05$

before $\mathrm{N}$ addition (Figure $4 \mathrm{~A}$ and $\mathrm{B}$ ), and the square of correlation coefficients $\left(\mathrm{R}^{2}\right)$ are 0.100 and 0.266 ( $\mathrm{p}>0.05)$, respectively. However, $\mathrm{N}: \mathrm{P}$ stoichiometry of soil showed a significant relationship with the $\mathrm{N}$ and $\mathrm{P}$ content $\left(\mathrm{R}^{2}=\right.$ 0.619 and $0.839, \mathrm{p}<0.01)$ which was expressed to cubic curve after $\mathrm{N}$ addition. On the contrary, the correlated coefficient between $\mathrm{N}: \mathrm{P}$ and $\mathrm{N}, \mathrm{P}$ content was significantly reduced by $\mathrm{N}$ addition from 0.913 and 0.599 to 0.882 and 0.040 , respectively (Figure $4 \mathrm{C}$ and $\mathrm{D}$ ). Meanwhile, the correlation analysis showed that there was no significant relationship between $\mathrm{P}$ content and $\mathrm{N}: \mathrm{P}$ stoichiometry $(\mathrm{p}>0.05)$ after $\mathrm{N}$ addition. 

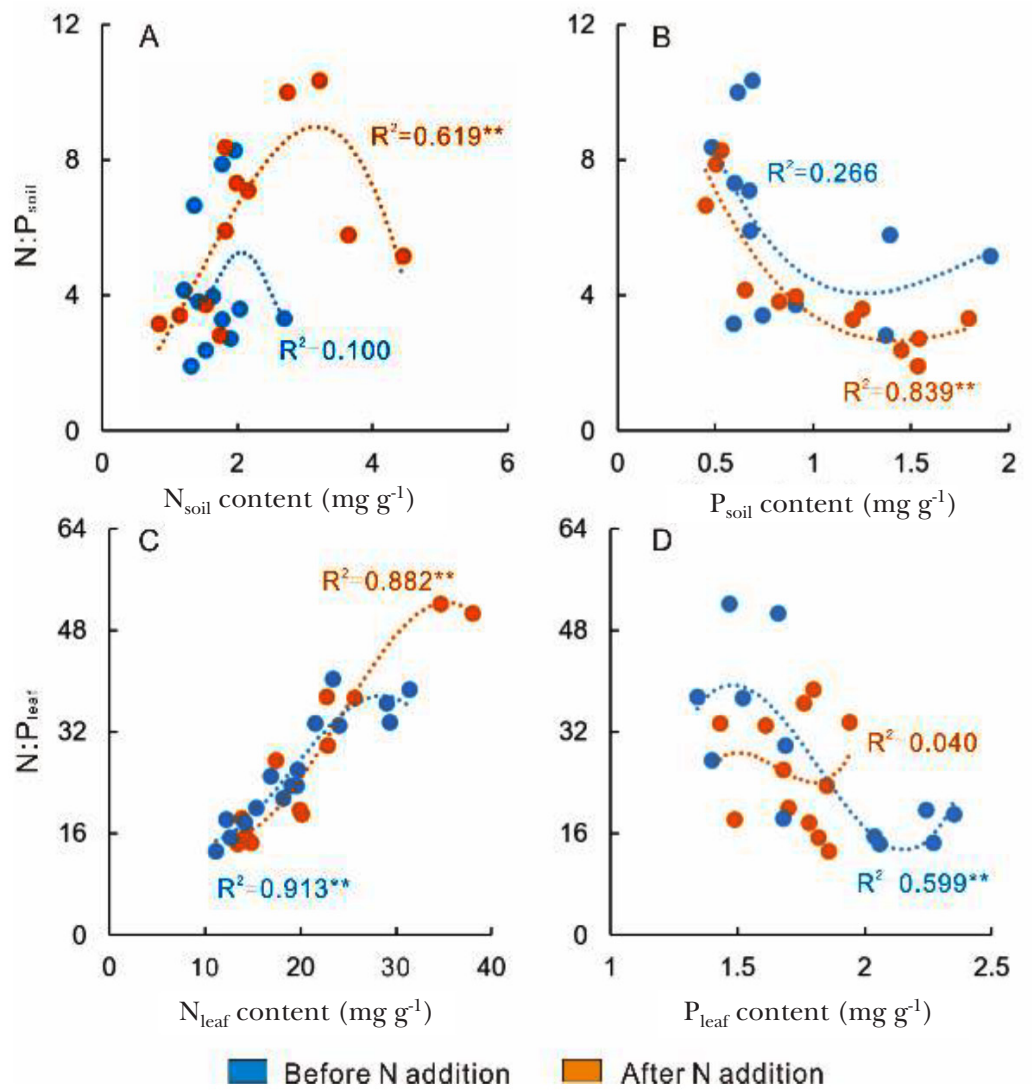

Figure 4 Relationship between N:P and N, P content in soil and leaves of XTR; (A) N content and N:P in soil, (B) $\mathrm{P}$ content and $\mathrm{N}: \mathrm{P}$ in soil, (C) $\mathrm{N}$ content and $\mathrm{N}: \mathrm{P}$ in the dominant species leaves, (D) $\mathrm{P}$ content and $\mathrm{N}: \mathrm{P}$ in the dominant species leaves; $*=$ significant at $\mathrm{p}<0.05, * *=$ significant at $\mathrm{p}<0.01$

\section{DISCUSSION}

Soil nutrients can affect the nutrient absorption and utilisation by plants directly, thereby changing the $\mathrm{N}$ and $\mathrm{P}$ stoichiometric characteristics, biomass allocation and ecological strategies in plants (Hogan et al. 2010). Exogenous nitrogen input can affect plant photosynthesis and growth by changing enzyme concentration and activity in plant leaves. (Fujita et al. 2010, Braun et al. 2010). Moreover, N:P in leaves can be used to indicate the nutrient limitation (mostly $\mathrm{N}$ or $\mathrm{P}$ ) of the driving force in ecosystem development (Güsewell \& Koerselman 2002). When N:P is less than 14, N limits plant growth. Plant growth may be limited by $\mathrm{N}$ and $\mathrm{P}$ element equally (co-limitation), at $\mathrm{N}: \mathrm{P}$ ratio within the range of 14 to 16 . When the $\mathrm{N}: \mathrm{P}$ ratio is greater than 16 , community biomass production is P-limited (Koerselman \& Meuleman 1996).

Analysis of the characteristics of foliar and soil ecological stoichiometry in XTR showed that the exogenous nitrogen input effectively increased the content of $\mathrm{N}$ in soil and restrained the absorption of $\mathrm{P}$ in a warm and humid climate, which significantly improved the N:P in soil. Meanwhile, the N:P of the plant leaves of the samples were more than 16 , except for individual samples, indicating that the plant growth of XTR is mainly restricted by $\mathrm{P}$, which is in accord with a recent study showing that most of the areas lack P elements (Gu et al. 2016). Under low $\mathrm{N}$ input, the $\mathrm{N}: \mathrm{P}$ of XTR plant leaves and P-limited were slightly reduced, but still indicating that the plant growth of XTR is mainly restricted by $\mathrm{P}$. This is probably because the dominant plant species accelerate growth as more $\mathrm{N}$ gather in plant litter by regulating enzyme synthesis and photosynthesis, and reducing the $\mathrm{N}$ content and $\mathrm{N}: \mathrm{P}$ of leaves. However, in high $\mathrm{N}$ input, $\mathrm{N}$ accumulation has destroyed the balance of nutrients and restrained the photosynthetic capacity of plants (Harpole \& Tilman 2007). Moreover it has 
affected the growth of plants, and significantly enhanced the N:P value and P-limited. The result is in accordance with previous studies in Amazon tropical rainforest, subtropical forest in SE China and temperate forest in NE United States (Bauer et al., 2004, Townsend et al. 2007, Huang et al. 2012). That is, exogenous nitrogen input will generate a threshold effect on plant growth (Clark \& Tilman 2008).

It is generally accepted that increased utilisation of $\mathrm{N}$ can promote rapid growth of high-N conversion plants, when excess nitrogen enters the ecosystem, and replace the low-N conversion plants (Stevens et al. 2004). For XTR ecosystem, especially in high $\mathrm{N}$ input, the P-limited will become more obvious. Both, species richness and diversity of rainforest ecosystem will decrease under long-term succession, and aggravate the degree of plaque in XTR.

\section{CONGLUSIONS}

The effects of $\mathrm{N}$ exogenous input on the ecosystem of XTR was studied by $\mathrm{N}$ addition experiment. The characteristics of $\mathrm{N}$ and $\mathrm{P}$ stoichiometry of soil and leaves indicated that the $\mathrm{N}$ content and $\mathrm{N}: \mathrm{P}$ in soil increased significantly in different levels of $\mathrm{N}$ addition, especially in low $\mathrm{N}$ addition. The $\mathrm{P}$ content in soil and leaves was generally reduced or flat compared with those before $\mathrm{N}$ addition. The N:P stoichiometry of soil had a significant relationship with the $\mathrm{N}$ and $\mathrm{P}$ content, which was expressed to cubic curve after $\mathrm{N}$ addition. However, the correlated coefficient between N:P and N, P content represented an opposing trend in plant leaves. It indicated that the impact of $\mathrm{N}$ deposition on the balance of the ecological system of XTR is more significant. Therefore, further enhancement of $\mathrm{N}$ deposition may exacerbate the plight of $\mathrm{P}$-scarce in tropical rainforest ecosystem, and aggravate the degree of plaque in XTR.

\section{ACKNOWLEDGMENTS}

The study was funded by the Reserve Talents of Young and Middle-aged Academic Technology Leaders of Yunnan Province (No. 2015HB029), and the National Natural Science Foundation of China (No. 41461015). Special thanks are due to $\mathrm{Wu}$ Mengjuan for the laboratory work. The comments and suggestions from the editor and anonymous reviewers were very helpful in improving the quality of the article.

\section{REFERENCES}

Bauer GA, Bazzaz FA, Minocha R, Long S, Magill A, Aber J \& BERNTSON GM. 2004. Effects of chronic N additions on tissue chemistry, photosynthetic capacity, and carbon sequestration potential of a red pine (Pinus resinosa Ait.) stand in the NE United States. Forest Ecology and Management 196: 173-186. https:// doi.org/10.1016/j.foreco.2004.03.032.

Braun S, Thomas VFD, Quiring R \& FlüCKiger W. 2010. Does nitrogen deposition increase forest production? The role of phosphorus. Environmental Pollution 158: 2043-2052. http://doi.org/10.1016/j. envpol.2009.11.030.

Clark CM \& Tilman D. 2008. Loss of plant species after chronic low-level nitrogen deposition to prairie grasslands. Nature 451: 71. http://doi.org/10.1038/ nature06503.

De Schrijver A, De Frenne P, Ampoorter E, Van Nevel L, Demey A, WuYTS K \& Verheyen K. 2011. Cumulative nitrogen input drives species loss in terrestrial ecosystems. Global Ecology and Biogeography 20: 803-816. http:// doi.org/10.1111/j.1466-8238.2011.00652.x.

FANG QL \& SHA LQ. 2006. Soil respiration in a tropical seasonal rain forest and rubber plantation in Xishuangbana. Journal Plant Ecology 30: 97-103. http://doi.org/10.17521/cjpe.2006.0014.

Fujita Y, Robroek BJM, Ruiter PCD, HeIL GW \& WASSEN MJ. 2010. Increased $N$ affects $P$ uptake of eight grassland species: the role of root surface phosphatase activity. Oikos 119: 1665-1673. http://doi.org/10.1111/ j.1600-0706.2010.18427.x.

Galloway JN \& Sutton MA. 2008. Transformation of the nitrogen cycle: Recent trends, questions, and potential solutions. Science 320: 889-892. http://doi. org/10.1126/science.1136674.

Giardina CP \& Ryan MG. 2002. Biogeochemistry: Soil warming and organic carbon content reply. Nature 408: 789-790. http://doi.org/10.1038/35048675.

Gu FX, Huang M, Zhang YD, Yan HM, Li J, Guo R \& Zhong XL. 2016. Modeling the temporal-spatial patterns of atmospheric nitrogen deposition in China during 1961-2010. Acta Ecologica Sinica 36: 3591-3600. http://doi.org/10.5846/stxb201409211868.

Guo Z, Chen S, Yang Q \& Zhuang M. 2014. Effects of mulching management on soil and foliar $\mathrm{C}, \mathrm{N}$ and $\mathrm{P}$ stoichiometry in bamboo (Phyllostachys violascens). Journal of Tropical Forest Science 26: 572-580.

Güsewell S \& Koerselman W. 2002. Variation in nitrogen and phosphorus concentrations of wetland plants. Perspectives in Plant Ecology Evolution and Systematics 5: 37-61. http://doi.org/10.1078/1433-8319-0000022.

HAN WX, Fang JY, GuO D \& Zhang Y. 2005. Leaf nitrogen and phosphorus stoichiometry across 753 terrestrial plant species in China. New Phytologist 168: 377-385. http://doi.org/10.1111/j.1469-8137.2005.01530.x.

Harpole WS \& Tilman D. 2007. Grassland species loss resulting from reduced niche dimension. Nature 446: 791-793. http://doi.org/10.1038/nature05684.

Hogan EJ, Minnullina G, Sheppard LJ, Leith ID \& Crittenden PD. 2010. Response of phosphomonoesterase activity in the lichen Cladonia portentosa to nitrogen and phosphorus enrichment in a field manipulation experiment. New Phytologist 186: 926-933. http:// doi.org/10.2307/40661417. 
Huang WJ, Zhou GY, Liu JX, Zhang DQ, Xu ZH \& Liu SZ. 2012. Effects of elevated carbon dioxide and nitrogen addition on foliar stoichiometry of nitrogen and phosphorus of five tree species in subtropical model forest. Environmental Pollution 168: 113-120. http://doi.org/10.1016/j.envpol.2012.04.027.

Koerselman W \& Meuleman AFM. 1996. The vegetation N:P ratio: a new tool to detect the nature of nutrient limitation. Journal of Applied Ecology 33: 1441-1450. http://doi.org/10.2307/2404783.

Li Y, Li Q, GuO D, Liang S \& WANG Y. 2016. Ecological stoichiometry homeostasis of leymus chinensis, in degraded grassland in western Jilin province, NE China. Ecological Engineering 90: 387-391. http:// doi.org/10.1016/j.ecoleng.2016.01.079.

Liu XJ, Ying Z, Han WX et aL. 2013. Enhanced nitrogen deposition over China. Nature 494: 459-462. http:// doi.org/10.1038/nature11917.

Lu TP, Wang YF, Wang LM, Lin YJ, Wu MJ, Zhang WX \& NiU J. 2018. Effect of the humidity/aridity gradient on the ecological stoichiometry of soil and leaves in Xishuangbanna tropical rainforest. Acta Ecologica Sinica 38: 2333-2343. http://doi:10.5846/ stxb201705020797.

Lu TP, Zhang WX, Niu J, Shi ZT, Lin YJ, Wu MJ \& Wang LX. 2017. The vertical characteristics of soil carbon and nitrogen at different rubber plantation ages in Xishuangbanna, southwest China. Fresenius Environmental Bulletin 26: 1431-1439.

Lü XT, Reed S, Yu Q, He NP, Wang ZW \& Han XG. 2013. Convergent responses of nitrogen and phosphorus resorption to nitrogen inputs in a semiarid grassland. Global Change Biology 19: 2775-84. http://doi. org/10.1111/gcb.12235.

Mori T, Imai N, Yokoyama D, Mukai M \& Kitayama K. 2017. Effects of selective logging and application of phosphorus and nitrogen on fluxes of $\mathrm{CO} 2, \mathrm{CH} 4$ and $\mathrm{N} 2 \mathrm{O}$ in lowland tropical rainforests of borneo. Journal of Tropical Forest Science 29: 248-256.

Murphy J \& Riley JP. 1962. A modified single solution method for the determination of phosphate in natural waters. Analytica Chimica Acta 27: 31-36. http:/ / doi. org/10.1016/S0003-2670(00)88444-5.

Myers N, Mittermeier RA, Mittermeier CG, DA FG \& Kent J. 2000. Biodiversity hotspots for conservation priorities. Nature 403: 853-858. http://doi. org $/ 10.1038 / 35002501$.
SALA OE \& WALL DH. 2000. Global biodiversity scenarios for the year 2100. Science 287: 1770-1774. http://doi. org/10.1126/science.287.5459.1770.

Stevens CJ, Dise NB, Mountford JO \& Gowing DJ. 2004. Impact of nitrogen deposition on the species richness of grasslands. Science 303: 1876. http:/ / doi. org/10.1126/science.1094678.

Storkey J, Macdonald AJ, Poulton PR et al. 2015. Grassland biodiversity bounces back from long-term nitrogen addition. Nature 528: 401-404. http://doi. org/10.1038/nature 16444 .

Sutton MA \& BleEker A. 2013. The shape of nitrogen to come. Nature 494: 435-437. http:/ /doi.org/10.1038/ nature11954.

Tessier JT \& Raynal DJ. 2003. Vernal nitrogen and phosphorus retention by forest understory vegetation and soil microbes. Plant $\mathcal{E}$ Soil 256: 443-453. http:/ / doi.org/10.1023/A:1026163313038.

Townsend AR, Cleveland CC, Asner GP \& Bustamante MM. 2007. Controls over foliar N:P ratios in tropical rain forests. Ecology 88: 107-118. http://doi. org/10.1890/0012-9658(2007) 88[107:COFNRI] . $0 . \mathrm{CO} ; 2$.

Xu ZW, Yu GR, Zhang XY eT AL. 2017. Soil enzyme activity and stoichiometry in forest ecosystems along the north-south transect in eastern China NSTEC. Soil Biology and Biochemistry 104: 152-163. http://doi. org/10.1016/j.soilbio.2016.10.020.

Zhang WX, Niu J, Ming QZ et al. 2018. Holocene climatic fluctuations and periodic changes in the Asian southwest monsoon region. Journal of Asian Earth Science 156: 90-95. http://doi.org/10.1016/j. jseaes.2018.01.003.

Zhao N, He N, Wang Q, Zhang X, Wang R, Xu Z \& Yu G. 2014. The altitudinal patterns of leaf C:N:P stoichiometry are regulated by plant growth form, climate and soil on changbai mountain, China. Plos One 9: e95196. http://doi.org/10.1371/journal. pone.0095196.

ZHU H. 2012. Biogeographical Divergence of the Flora of Yunnan, Southwestern China Initiated by the Uplift of Himalaya and Extrusion of Indochina Block. Plos One 7: e45601. http://doi.org/10.1371/journal. pone. 0045601 . 